\title{
Sosialisasi Prosedur Isolasi Mandiri Selama Covid 19 Melalui Video Edukasi Bagi Warga Kelurahan Dondang Kabupaten Kutai Kartanegara
}

\author{
Gamar Al Haddar ${ }^{1}$, Niken Novita Sari ${ }^{2}$ \\ ${ }^{1,2}$ Universitas Widya Gama Mahakam Samarinda, Indonesia \\ 1*gamar@uwgm.ac.id
}

\begin{abstract}
Corona Virus or what we often call covid 19. According to the World Health Organization (WHO) is a virus that causes infections in the respiratory tract such as mild flu, shortness of breath to more severe respiratory infections such as MERS-CoV and SARS-CoV. This corona virus is also zoonotic. At this time the corona virus or Covid-19 re-emerged which initially caused an outbreak that occurred in China, more precisely the city of Wuhan in December 2019, and spread throughout the world including Indonesia.

In the midst of the ongoing Covid-19 pandemic and the increasing number of people who are positive for Covid-19, preventive measures for the transmission of the corona virus must be increasingly enforced, for example, such as self-quarantine and the public must be aware of the dangers posed by this virus. In addition to prevention, we must also know how to self-quarantine procedures that are good and correct because this can be useful for us to save yourself and can also save others so that this chain of distribution can be broken. In this case, community service activities are carried out by distributing videos on how to self-isolate for people in the Dondang Village, Kutai Kartanegara Regency.
\end{abstract}

Keywords: Covid-19, self Isolate

\begin{abstract}
Abstrak
Corona Virus atau yang sering kita sebut dengan sebutan covid 19. Menurut World Health Organization (WHO) virus merupakan salah satu virus yang menyebabkan infeksi pada saluran pernapasan seperti flu ringan, sesak napas hingga infeksi pernapasan yang lebih parah seperti MERS-CoV dan SARS-CoV. Virus corona inipun bersifat zoonosis. Pada saat ini virus corona atau Covid-19 kembali muncul yang pada awalnya menyebabkan wabah yang terjadi pada Negara China, lebih tepatnya kota Wuhan pada Desember 2019, dan menyebar hingga keseluruh dunia termasuk Indonesia.

Ditengah pandemi Covid-19 yang sedang terjadi ini dan semakin banyaknya orang yang positif mengidap Covid-19 maka tindakan pencegahan penularan virus corona harus semakin ditegakkan contohnya seperti isolasi mandiri dan masyarakat pun harus sadar akan bahaya yang ditimbulkan dari virus ini. Selain pencegahan kitapun harus tahu bagaimana prosedur isolasi mandiri yang baik dan benar dikarenakan hal ini dapat berguna bagi kita untuk menyelamatkan diri anda sendiri dan dapat juga menyelamatkan orang lain sehingga mata rantai penyebaran ini dapat diputuskan Dalam hal ini kegiatan pengabdian dilakukan dengan menyebarkan video cara isolasi mandiri bagi masyarakat yang ada di kelurahan dondang kabupaten Kutai Kartanegara.
\end{abstract}

Kata Kunci: Covid-19, Isolasi Mandiri

\section{PENDAHULUAN}

Corona Virus atau yang sering kita sebut dengan sebutan covid 19. Menurut World Health Organization (WHO) virus merupakan salah satu virus yang menyebabkan infeksi pada saluran pernapasan seperti flu ringan, sesak napas hingga infeksi pernapasan yang lebih parah seperti MERS-CoV dan SARS-CoV. Menurut Annisa Salsabila (2020) Virus corona inipun bersifat zoonosis yaitu virus ini dapat ditularkan antara hewan dan manusia. Tidak menutup kemungkinan bahwa manusia dapat tertular virus ini melalui hewan, dikarenakan para ilmuwan telah mengemukakan hasil penelitiannya bahwa virus ini dapat menginfeksi tikus, kucing, burung, anjing dan hewan lainnya.

Virus corona ini bertanggung jawab atas kejadian yang menyebabkan terjadinya wabah yang sekarang melanda seluruh dunia, termasuk pula Pandemi Severe Acute Respiratory Syndrome (SARS) 2002-2003 dan wabah Middle East Respiratory Syndrome (MERS) di 
Korea Selatan pada tahun 2015. Pada saat ini virus corona atau Covid-19 kembali muncul yang pada awalnya menyebabkan wabah yang terjadi pada Negara China, lebih tepatnya kota Wuhan pada Desember 2019, dan menyebar hingga keseluruh dunia sehingga World Health Organization (WHO) menyatakan bahwa kejadian ini sebagai Pandemi Global.

Menurut Rezky Amaliah Usman,Raden Roro, Rusdi (2020) Virus corona atau Covid19 ini pun telah melanda Negara kita yaitu Indonesia lebih tepatnya pada tanggal 2 Maret 2020 pemerintah menyatakan bahwa terdapat terdapat adanya dua kasus orang yang telah mengidap atau positif Covid-19. Hal ini pun membuat pemerintah dan masyarakat menjadi panik dikarenakan penyebarannya virus ini cukup cepat. Sehingga dikhawatirkan akan semakin banyak orang yang terpapar Covid-19. Menurut Wikipedia (2020) terlebih lagi dikarenakan hingga saat ini belum ditemukannya vaksin yang dapat menangani virus ini, sedangkan kejadian ini sudah sangat banyak menelan korban jiwa maupun pasien yang positif.

Pemerintah pun telah melakukan langkah-langkah guna mengantisipasi penyebaran virus ini semakin meluas diantaranya yaitu seperti mensosialisasikan gerakan Social Distancing, memakai masker jika berada ditempat umum, mencuci tangan atau menggunakan hand sanitizer sebelum dan sesudah berkegiatan. Social Distancing merupakan konsep yang dapat diartikan bahwa kita dapat mengurangi bahkan memutus mata rantai penyebaran Covid-19. Hal ini dapat dilakukan dengan cara menjaga jarak aman dengan orang lain setidaknya 2 meter, tidak melakukan kontak secara langsung dengan orang lain dan tidak menghadiri pertemuan yang melibatkan banyak orang.

Adapun jika kita berada di suatu wilayah yang telah terpapar Covid-19 atau jika kita merasa telah bertemu orang yang terinfeksi Covid-19 maka kita sebaiknya melakukan karantina mandiri. Hal ini dimaksudkan agar kita tidak menyebarkan atau menularkan virus tersebut kepada orang lain sehingga kita dapat memutus mata rantai penyebaran tersebut. Karena Covid-19 ini dapat menular melalui percikan air liur ketika batuk atau bersin, ataupun bisa juga melalui benda yang kita pegang yang terlebih dahulu telah disentuh oleh pengidap virus corona..

\section{METODE PELAKSANAAN}

Metode yang dilakukan dalam pengabdian ini yakni sosialisasi melalui media sosial group dengan menggunakan video cara isolasi mandiri. Pelaksaan membagikan Video Edukasi ini melalui media WhatsApp pada hari Selasa, 25 Agustus 2020. Video edukasi ini dibagikan melalui grup WhatsApp Staf Kelurahan Dondang, Tim Masyarakat Peduli, Forum Komunikasi MPA, MPRT, LPM dan Kelurahan Dondang. Tujuan kegiatan adalah agar masyarakat khususnya masyarakat Kelurahan Dondang mengetahui bagaimana cara atau prosedur dalam melaksanakan karantina mandiri sebagai bentuk tindakan antisipasi ataupun juga jika ada sesuatu yang tidak inginkan terjadi maka mereka dapat menerapkan prosedur tersebut

\section{HASIL DAN PEMBAHASAN}

Ditengah pandemi Covid-19 yang sedang terjadi ini dan semakin banyaknya orang yang positif mengidap Covid-19 maka tindakan pencegahan penularan virus corona harus semakin ditegakkan contohnya seperti karantina mandiri dan masyarakat pun harus sadar akan bahaya yang ditimbulkan dari virus ini. Selain pencegahan kitapun harus tahu bagaimana prosedur karantina mandiri yang baik dan benar dikarenakan hal ini dapat berguna bagi kita untuk menyelamatkan diri anda sendiri dan dapat juga menyelamatkan orang lain sehingga mata rantai penyebaran ini dapat diputuskan. Namun dengan adanya 
prosedur karantina mandiri ini tidak akan menghalangi kegiatan kita seperti biasa hanya saja cara pelaksanaannya yang berbeda.

Ketahuilah prosedur karantina mandiri yang baik dan benar:

1. Tetap di Rumah Saja

Tetap di rumah saja atau yang dikenal dengan sebutan Stay at Home merupakan suatu kondisi dimana kita melakukan semua kegiatan secara online atau daring dari rumah masing-masing contohnya seperti berkerja, sekolah, kegiatan berbisnis dan lain sebagainya. Hal ini dimaksudkan agar kita tidak bertemu dengan orang lain secara langsung sehingga kita dapat mencegah penyebaran virus corona tersebut.

2. Periksa Suhu Anda

Periksa suhu tubuh anda setidaknya 2 kali sehari karena hal ini merupakan suatu tindakan mengontrol bagaimana keadaan anda dari waktu ke waktu. Hal ini dilakukan karena salah satu gejala yang ditunjukkan jika anda terjangkit virus corona yaitu demam.

3. Gejala Covid-19

Jika seseorang terjangkit virus corona maka tubuh mereka menimbulkan gejalagejala tertentu selain demam, contohnya yaitu:

a. Kelelahan atau tubuh terasa lemas

b. Sesak napas

c. Batuk tidak berdahak

d. Pegal-pegal

e. Tidak nafsu makan

f. Hilangnya kemampuan dalam mengecap rasa ataupun mencium aroma-aroma.

Karena Covid-19 disebabkan oleh virus yang menyerang saluran pernapasan maka gejala awal Covid-19 pun juga bisa sama seperti flu biasa, contohnya seperti pilek, sakit kepala, sakit tenggorokan, hidung tersumbat. Namun pada umumnya sesak napas mulai dirasakan pada minggu kedua. Adapula gejala lain seperti diare, perut terasa tidak nyaman bahkan mual akan tetapi gejala ini jarang terjadi dan hanya beberapa orang saja yang mengalami nya.

4. Terapkan Pembatasan Sosial

Terapkan pembatasan sosial atau yang sering disebut dengan istilah Social Distancing merupakan suatu keadaan dimana kita diharuskan menjaga jarak dengan orang lain setidaknya +1 Meter. Hal ini dimaksudkan agar tidak terlalu dekat dengan orang lain dan menghindari kerumunan yang melibatkan banyak orang yang dapat berakibat dengan mudahnya menyebarkan virus corona atau Covid-19.

5. Cuci tangan

Pada kegiatan cuci tangan ini kita tidak boleh asal mencuci tangan saja karena dapat berakibat tidak mati nya kuman atau virus yang ada ditangan. Oleh karena itu, kita diharuskan mencuci tangan dengan menggunakan sabun dan pada air yang mengalir bukan pada wadah yang berisi air._World Health Organization (WHO) pun telah mensosialisasikan bagaimana cara mencuci tangan yang baik dan benar yaitu sebagai berikut:

a. Telapak Tangan (gosok kedua telapak tangan anda)

b. Punggung Tangan (gosok punggung dan sela-sela jari sisi luar tangan kiri dan tangan kanan)

c. Sela-Sela Jari (gosok sela-sela jari bagian dalam)

d. Kunci Jari (kunci jari-jari sisi dalam dari kedua tangan)

e. Putar Ibu Jari (gosok ibu jari tangan kiri dan putar dalam genggaman tangan kanan dan lakuan sebaliknya) 
f. Putar Semua Ujung Jari (rapatkan ujung jari tangan kanan dan gosokkan pada telapak tangan kiri)

g. Putar Pergelangan Tangan (bersihkan kedua pergelangan tangan secara bergantian dengan gerakan memutar)

h. Keringkan Tangan (keringkan kedua tangan anda)

i. Tutup Keran Dengan Siku (tutup keran dengan siku atau bekas kertas tisu yang masih di tangan)

6. Tetap di Ruangan Khusus dan Alat Makan Secara Khusus

Tetap di ruangan khusus dimaksudkan jika seseorang sudah terinfeksi virus corona maka orang tersebut harus berada diruangan khusus sehingga tidak memungkinkannya untuk berkontak langsung dengan orang lain terutama orang yang sehat (bebas Covid19). Hal ini tidak hanya berhubungan dengan ruangan tetapi juga alat makan yang digunakan oleh orang yang terinfeksi virus ini dikarenakan virus ini juga dapat menular melalui benda yang digunakan oleh penderita. Jika memungkinkan sebaiknya juga menggunakan toilet secara khusus sehingga tidak dapat menyebarkan virus ini kepada orang lain.

7. Hubungi Pihak Rumah Sakit

Pada hal ini dimaksudkan agar jika seseorang terinfeksi virus corona atau terkena Covid-19 maka diharuskan menghubungi atau memberitahu terlebih dahulu jika akan mengunjungi Dokter atau Rumah Sakit. Hal ini bertujuan agar pihak rumah sakit atau dokter dapat mempersiapkan diri terlebih dahulu contohnya seperti memakai Alat Perlindungan Diri (APD). Jika kita tidak memberitahukan terlebih dahulu maka hal ini dapat berakibat fatal kepada tenaga media ataupun orang yang mengunjungi rumah sakit karena bisa saja mereka tertular virus yang ada pada diri anda.

Itulah hal-hal yang perlu kita ketahui tentang prosedur karantina mandiri yang baik dan benar. Kita juga perlu menerapkan hidup bersih dan juga jangan lupa mencuci tangan sebelum dan sesudah beraktivitas.

Berdasarkan prosedur karantina mandiri yang dipaparkan di atas merupakan salah satu metode pencegahan penularan virus corona kepada orang lain. Prosedur-prosedur yang telah dijabarkan diatas tidak hanya kita lakukan pada saat pendemi saja akan tetapi harus kita lakukan setiap saat karena hal itu akan berdampak baik pada diri dan tubuh kita sendiri. Alangkah baiknya jika kita tidak lagi menyepelekan keadaan ini secara berkelanjutkan dikarenakan hal ini justru akan semakin memperparah pandemi ini dan bahkan bisa saja korban selanjutnya anda atau orang terdekat anda. Oleh karena itu sebaiknya kita tetap tetap menaati peraturan pencegahan penyebaran Covid-19 yang telah digalakkan oleh pemerintah dengan baik dikarenakan COVID-19 ini memiliki penyebaran yang sangat cepat terbukti hanya dalam hitungan bulan ia telah menelan korban jiwa yang sangat banyak dari segala negara. 
JPAY Vol. 1 No. 1.2021

URL:

http://www.sttibontang.ac.id/jurnal/index.php/pay

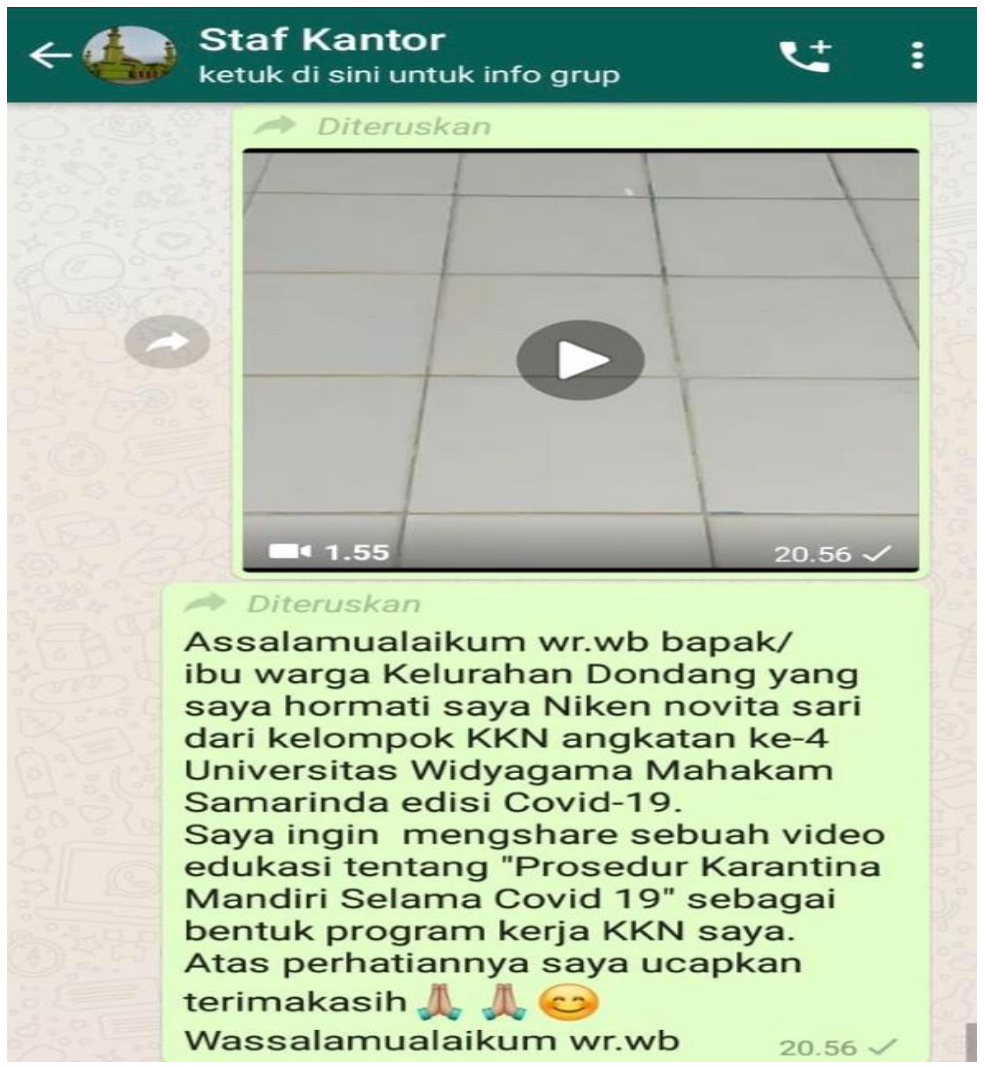

Gambar 1. Dokumentasi membagikan Video Edukasi di Grup WhatsApp Staf Kelurahan Dondang.

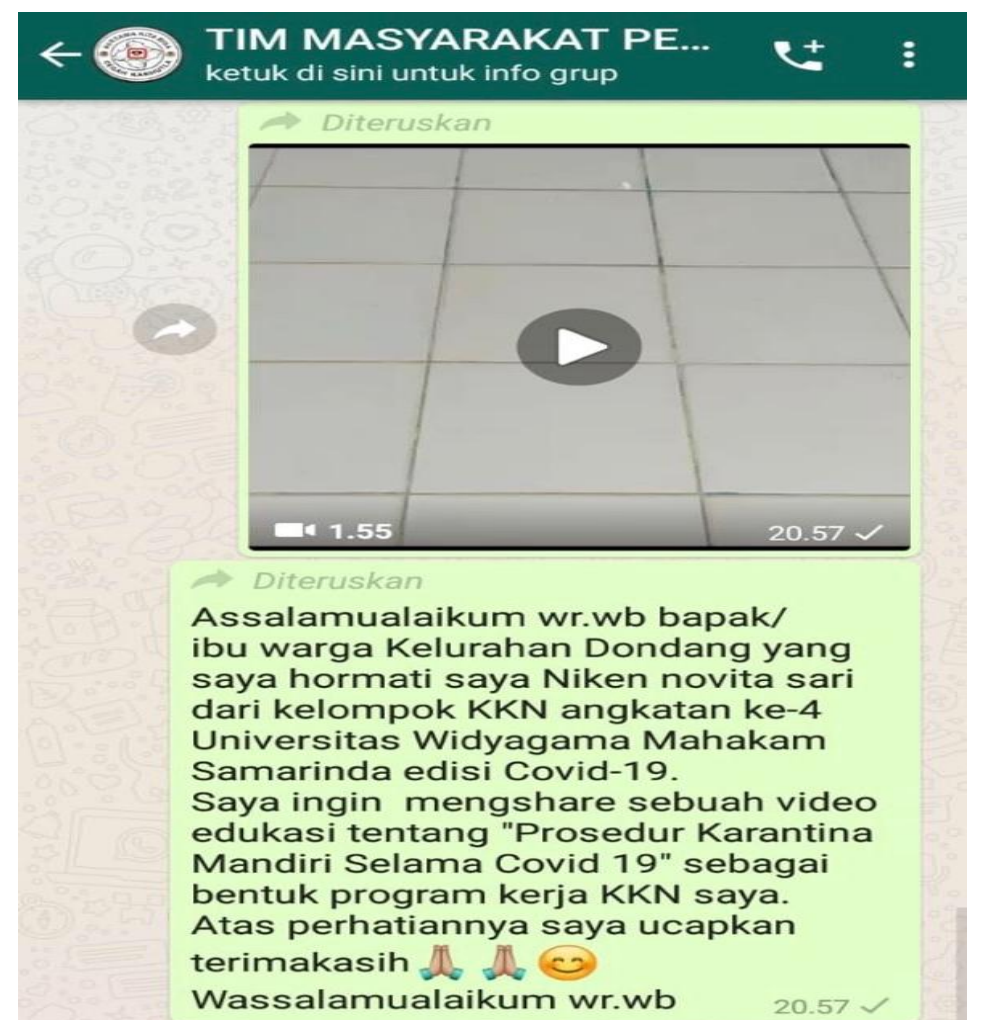


Gambar 2. Dokumentasi membagikan Video Edukasi di Grup WhatsApp Tim Masyarakat Peduli

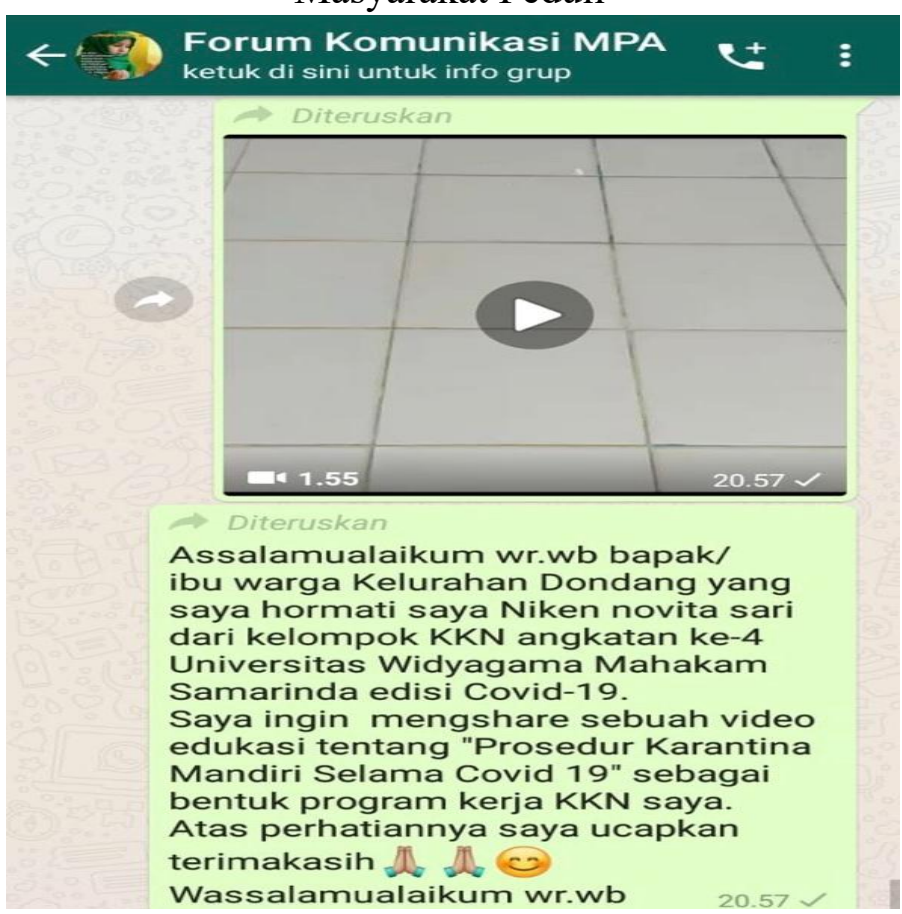

Gambar 3. Dokumentasi membagikan Video Edukasi di Grup WhatsApp Forum Komunikasi MPA.

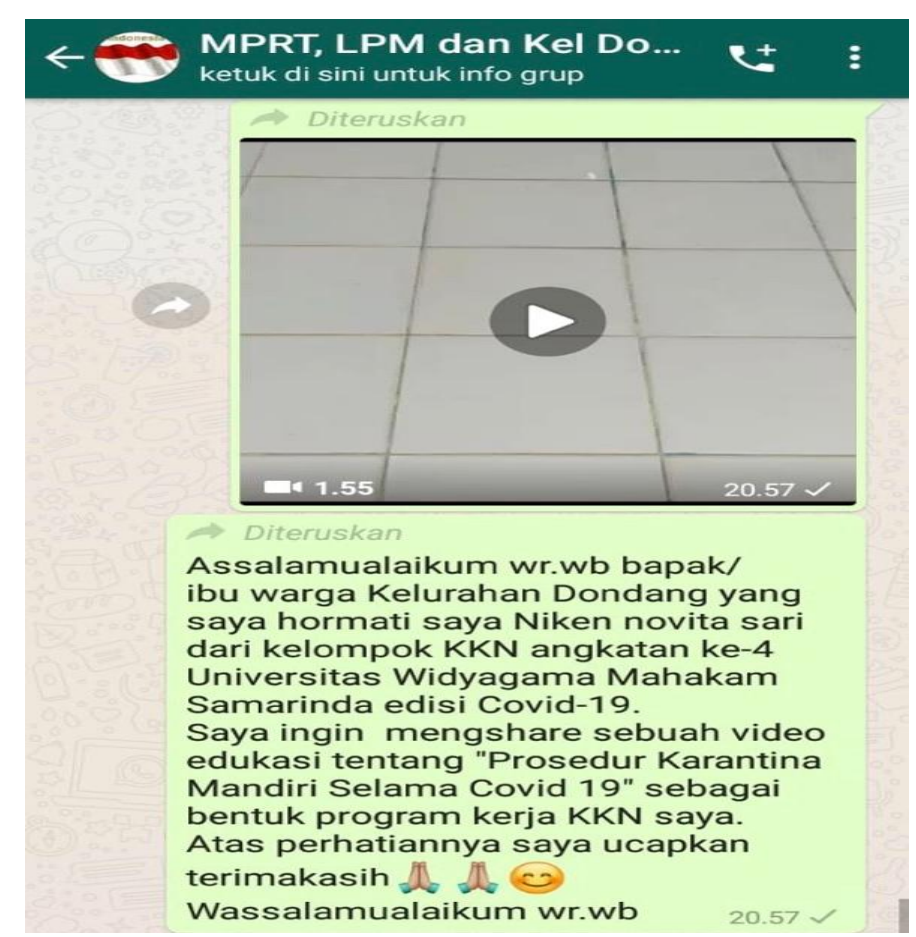

Gambar 4. Dokumentasi membagikan Video Edukasi di Grup WhatsApp MPRT,

LPM dan Kelurahan Dondang.

Virus corona atau Covid-19 bukanlah suatu hal yang bisa kita anggap remeh dikarenakan virus ini tidak dapat kita lihat melalui kasat mata. Dengan kita meremehkan hal ini maka akan memberikan suatu dampak yang sangat buruk pada diri kita bahkan dunia. 
Seharusnya sebagai masyarakat yang baik kita harus pandai dalam menyikapi hal ini dan tetap menerapkan gaya hidup yang baik, benar dan bersih.

Kita pun harus membantu pemerintah dengan tetap menaati prosedur pencegahan penyebaran Covid-19 dengan cara tetap memakai masker, rajin mencuci tangan atau memakai hand sanitizer dan tetap menjaga jarak dengan orang lain setidaknya 1 meter. Kita pun sebaiknya menghindari tempat ramai yang dapat memicu penyebaran ini semakin cepat contohnya pusat perbelanjaan modern, pasar tradisional, ataupun teman makan kecuali jika dalam kondisi mendesak.

\section{Ucapan terimakasih (jika diperlukan)}

Penulis mengucapkan terima kasih kepada Universitas Widya Gama Mahakam Samarinda yang telah memberikan dukungan dan arahan untuk kegiatan pengabdian kepada masyarakat ini. Penulis juga mengucapkan terimakasih kepada lurah Dondang, dan seluruh jajarannya yang telah memberikan izin dan membantu terselenggaranya kegiatan ini. Penulis juga mengucapkan terimaksih kepada seluruh Ketua RT Kelurahan Dondang yang telah bekerja sama untuk melaksanakan program kerja ini.

\section{DAFTAR PUSTAKA}

Salsabila, A. (2020). Makalah Penyakit Menular Danvirus Corona. 8. https://osf.io/zexc9

Usman, R. A., Roro, R., \& Rusdi. (2020). Sosialisasi Hidup Sehat Di Tengah Wabah Virus Corona. http://jurnal.stikeswhs.ac.id/index.php/pengmas/article/view/157

Wikipedia. (2020). Korona virus. https://id.wikipedia.org/wiki/Koronavirus

https://id.wikipedia.org/wiki/Dondang,_Muara_Jawa,_Kutai_Kartanegara (diakses pada tanggal 2 September 2020)

\section{Profil Penulis:}

\begin{tabular}{|l|l|}
\hline & $\begin{array}{l}\text { Gamar Al Haddar, Penulis merupakan salah satu Dosen di } \\
\text { Universitas Widya Gama Mahakam Samarinda Program Studi } \\
\text { Pendidikan Guru Sekolah Dasar. Email penulis yakni } \\
\text { gamar@uwgm.ac.id }\end{array}$ \\
\hline & $\begin{array}{l}\text { Niken Novita Sari merupakan salah satu mahasiswa } \\
\text { Universitas Widya Gama mahakam Samarinda Program Studi } \\
\text { Pendidikan Guru Sekolah Dasar. Email penulis yakni } \\
\text { nikennovita63@gmail.com }\end{array}$ \\
\hline
\end{tabular}

